\title{
A brave one-legged general: The story of Mau Mau General, Kassam Gichimu Njogu
}

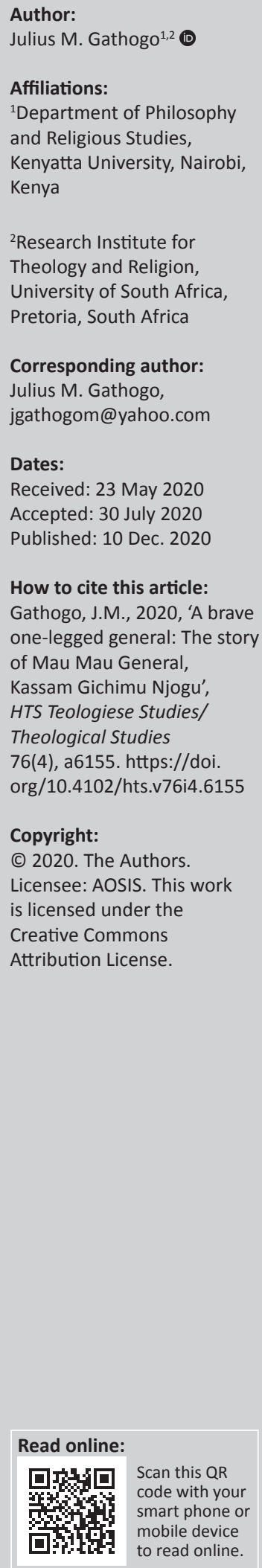

This article sets out to demonstrate the role of the 'one-legged devil' (as the colonialists called Patrick Gichimu Njogu), also called General Kassam. Kassam was one of the pioneer generals of the Mau Mau, a guerrilla movement that operated from the central Kenya forests as they participated in the war of liberation from the early 1950s to the early 1960s. Was Kassam a one-legged general from the word go? Methodologically speaking, the article is partially based on interviews conducted with the general before his death at the age of 89 in 2011. Being an insider, Kassam helped to give an in-depth understanding of the Mau Mau war of independence by relating the role of the Kavirondo people of western Kenya in Mau Mau historiography. Were they enticed by the colonial government to abandon the idea of the armed struggle as a way of writing off colonialism? Or did the Kavirondo (western Kenya) embrace the theology of non-violence (and pacifism) and eventually left the central Kenya group to battle it alone? Or were the people of western Kenya dissuaded to take part in the struggle by the Christian 'gospel of love' that abhorred violence, leading to abandoning their colleagues from central Kenya at the last minute? Theoretically speaking, the article is largely informed by John Walton's theory of reluctant rebels. Walton argues that rebels are always incited by the leading elites in a society that undergoes war or civil war at any given time in history.

Contribution: The article contributes to growing knowledge by discussing the Mau-Mau Movement in Kenya's quest for freedom, from the 1950s to early 1960s, to demonstrate the religious role of armed conflicts in Africa. In this case, General Kassam, a baptised Anglican Christian, whose loyalty to the ancestral pantheons drove him to the quasi-religious war of independence, is the key subject in this article. In this war of independence in Kenya, a seeming conflict between African religion and Christian religion appears as a key emerging issue. The article is relevant to the HTS Journal and the world of scholarship because it is a theoanthropocentric piece of work which deals with God, creation, and inevitable human conflicts all of which have answers before God.

Keywords: General Kassam; Mau Mau war; Kavirondo; Colonialism in Kenya; Mau Mau history in Kirinyaga.

\section{Introduction}

The year 2019 marked the eighth year since the time 'one-legged' Mau Mau General Kassam had met his Maker. If he had been physically present in 2019, the people of Kirinyaga County and the larger Embu district would have crooned (Gachau, interviewed, 20 December 2018):

‘ $[H]$ appy birthday to you Baba. You risked your life so as to give us dignity, freedom and identity as a people since 1950. You lost your left leg in the course of this, but your place in history is secure.'

Being the second Mau Mau general after Ndaya who hailed from the entire Embu district (now Kirinyaga and Embu counties), Kassam's name is placed on a pedestal whenever writers attempt to pen the history of the Kirinyaga County of Kenya. Indeed, Kassam remains one of the greatest makers of history in the modern Kirinyaga County and the Kenyan state.

Born in 1922, Kassam wrestled with the vicissitudes of life till he breathed his last in August 2011. As the erstwhile governor of Kirinyaga, Joseph Ndathi renamed Kianyaga Stadium as the General Kassam Njogu Stadium on 01 June 2017. He proclaimed as follows: 'The only thing we can remember him by is to name the stadium in his honour' (Kamau 2017:6). Kassam, who lost his left leg in 1953 while fighting for Kenya's independence, walked with crutches till his death at Tumu Tumu Hospital, Nyeri County. Similarly, it was suggested during the burial of General Matene of Gitumbi in June 2017 that the Kerugoya Stadium was to be named in his honour.

Note: Special Collection entitled Social Memory Studies, sub-edited by Christina Landman (UNISA) and Sekgothe Mokgoatšana (UL). 
Previously, general consensus had been that the KagumoKamuiru-Mutitu road would be named after another Mau Mau general, General Chui wa Mararo, who was slain in May 1956.

It is still hoped that the Kirinyaga County Assembly would deliberate on such proposals, albeit belated. An archive centre that would be named after General Chui wa Mararo has also been proposed at St Peter's Anglican Church, Kamuiru, where he was burnt to ashes upon capture by the colonial authorities. The General Chui wa Mararo archive centre has been envisaged since 2016. An archive and a tourist centre are set to be constructed at the actual site where Chui was burned to death in May 1956. In a nutshell, General Kassam did not fight alone. He had sergeants, brigadiers, inspectors, majors, privates and others under him. The war of independence was fought by both the forest fighters and others who were harassed in the villages from time to time.

Important to take note is that the official name of the movement that sought to achieve Kenya's independence by military means was the Kenya Land and Freedom Army. This was a guerrilla army that was mainly comprised of the people of central and eastern Kenya and that violently and with gusto resisted the British rule. It was counteracted with equal force, particularly after the end of 1954 when the 'terrorists' (Gathumbi, interviewed, 03 February 2018) in their mid-20s were bombed left, right and centre. They resisted the British rule from the 1940s to the early 1960s, though the 1950s turned out to be the most climactic period. Their overall leader was General Dedan Kimathi Wachiuri (1920-1957).

\section{Motivation}

The young rebels were motivated to fight a superior army and/or a well-equipped British army by the oppressive environment that was punctuated by heavy taxations (poll tax and hut tax), arbitrary arrests and beatings, land grabbings and evictions from their ancestral lands and general discrimination and downgrading in all sectors of their lives. In an interview a few years before he passed away in 2011, Kassam related that African soldiers who had returned from the Second World War (1939-1945) had told stories that demystified the idea of European superiority over black people. In particular, he noted a case where they saw a visibly timid European soldier painting himself black in order to appear fearsome.

Apart from the motivational factors noted above, the general motivation for fighting was a shared hatred of colonialism, as the rebels sought to recover Wiyathi na Ithaka (freedom and land). Kassam and his fellow Embu-Kirinyaga rebels were inspired by the formation of a platoon (called the Heka Heka platoon) by their neighbours in the Nyeri district at the end of 1951. Hence, as they formed Embu's Haraka platoon for the Embu district in May 1953, they had already interacted with brave young men from the present-day Nyeri County who were then led by General China. China, whose real name was Waruhiu Itote, liked staying on the Embu (and Kirinyaga) side of the border rather than in his native Nyeri County, which was a district then. China was once shot at Kariti in early 1953 but his soldiers carried him all the way to Gitumbi-Ndia near the Kangaita Tea Factory where he would be safe and where his wound could heal. He was subsequently moved from house to house to dodge his pursuers and avoid capture till he healed (Gachau, interviewed, 20 December 2018). He was a strong leader and people, such as Chui, Kassam, Magoto, Matene, Kubukubu, Major Judge and others, were emboldened by him.

\section{The state of emergency}

On 20 October 1952, Kenya's colonial governor, Sir Evelyn Baring (1903-1973), declared a state of emergency, which continued up to 10 January 1960 . This was indeed the longest state of emergency ever to be declared in colonial and postcolonial Kenya. The aim was to tame the likes of General Kassam and the Mau Mau rebels who were employing guerrilla tactics to demand Kenya's independence. In the ensuing war, tens of thousands of Kenyans, mainly in the central region, died in detention camps and in the 854 restricted villages that had been established. Baring was the colonial governor of Kenya who in early October 1952 issued orders for a ruthless crackdown on the Mau Mau freedom fighters. The immediate cause for the declaration of emergency was the brutal killing on 09 October 1952 of Chief Waruhiu from the present-day Kiambu County. As noted earlier, this declaration was after several confrontations between the rebels and the colonial authorities that led to the tension, the zenith of which was reached on 20 October 1952 when the national leaders, such as Jomo Kenyatta, Kung'u wa Karumba, Fred Kubai, Paul Ngei, Richard Ochieng' Oneko and Bildad Mwaganu Kagia, were arrested and later imprisoned for 7 years. Other African leaders who were arrested during the great swoop included Peter Gatabaki, Joel Kuria, Willy Wambugu Maina, Victor Wokabi, Gakaara Wanjau, Sarah Sarai and Rebecca Njeri. In this operation, dubbed 'Operation Jock Scott', more than 100 Africans were arrested and taken to prison camps in what was called the Northern Frontier District (NFD), later renamed North Eastern Province (Gathogo \& Mugo 2019:11).

During this period of emergency, which was vehemently opposed by General Kassam's team, Governor Baring issued emergency regulations that were meant to 'restore peace' (Gathogo 2017a:1-17; Gathogo \& Mugo 2019:11). For these 8 years, Africans were not allowed to drive, walk or travel around without written permits. They were also prohibited from carrying any weapons. Additionally, 600 officers from the Lancashire Fusiliers Battalion were flown over 2100 miles from the Canal Zone into Nairobi. Their purpose was to team up with the King's African Rifles (KAR) to 'restore peace and order' and most importantly to crush General Kassam's group of so-called terrorists. The KAR was a multi-battalion British colonial regiment raised from the various British possessions in East Africa from 1902 until 1960 (Gathogo 2014:21, Gathogo \& Mugo 2019:13). 
On 21 October 1952 (the day after the declaration of emergency), the Kenyan newspapers carried various headlines: 'Emergency Declared, New Law to Curb Violence', and so on. Specifically, the East African Standard carried the following headline: 'State of Emergency Is Proclaimed' and with a subtitle that read, 'Public Is Asked to Help Authorities' (Korir 2018:9). Furthermore, Governor Baring issued a signed statement which appeared in the local dailies and read as follows:

Owing to the prevalence of disorder in a part of Kenya, a state of emergency was declared throughout the colony and protectorate by proclamation signed by me last night. A number of emergency regulations have been made and under these, certain persons have been detained because it is considered necessary to exercise control over them for the purpose of maintaining public order. The grave step of proclaiming an emergency has been taken most unwillingly and with great reluctance by the Kenyan Government. But there was no alternative in face of mounting lawlessness in a part of the colony and there was no other method of keeping the peace and protecting the lives and property of innocent men of all races. All possible measures are being taken to prevent any disorder and to maintain essential services. For this purpose, there has been a redistribution of police and military forces and in addition, a British battalion is being brought by air to Nairobi, the first troops having arrived last night. The measures taken are aimed at those only who in the government's opinion are responsible directly and indirectly for violence and for the present state of disorder in a part of the colony. The Government has no intention of penalising anyone merely on account of their political views (Korir 2018:9).

\section{Kassam's roots}

General Kassam was born in 1922. His father, Njogu wa Kamara, was the richest man in the village and had many cattle. Kassam went to Nairobi in 1941 after primary school to escape what he thought was a demeaning life propagated by chiefs and their headmen, whom he saw as imperious and domineering for they had power over other people's properties and wives (Kassam, interviewed, 20 May 2008).

At the same time, the colonialists introduced terrace farming, which in practical terms boiled down to forced labour practices. The most aggravating part of it was when the chiefs demanded the digging of deep trenches even in areas that were flat. This was meant to make men angry and move away in search of employment on tea and coffee farms owned by European settler farmers. It was a deliberate attempt to drive young African men out because sooner or later a rebellion would foment (Kassam, interviewed, 20 May 2008).

Kassam was told that there was a military recruitment area where Nyayo House stands today in the capital city of Kenya, Nairobi. To his disappointment, although they were recruited, the recruits were taken first to work on a sisal plantation. At first, Kassam refused to work on the plantation, opting instead to do casual work at building sites in the city of Nairobi. While they were building Gill House in the city, a supervisor hit him for sitting down during working hours. He hit him back, which encouraged others to join in. It was the first rebellion that he claimed to have led in his lifetime. Next, he clashed with a European man on another building site and decided to stalk him for revenge. In his recollections, this man lived where Chester House stands today in Nairobi. He attacked him with a knife even though he had a pistol. He then escaped and went to work on a farm in Kiambu. There he met many young men who had beliefs similar to his. From this point onwards he was a rebel. They eventually formed a gang and he was one of the leaders. In today's terms, this gang may be described as criminal but in those days it was the only way they could hit back at colonial brutalities and dehumanisation (Kassam, interviewed, 20 May 2008).

In his view, they were a pack of nasty mobsters who did terrifying things to European men and Asians whom they did not agree with or who oppressed them when they worked in their businesses or firms. Kassam was an avowed outlaw and luckily he had his own followers, especially young men from Kiambu. The turning point came when he visited his parents' home in the late 1940s and saw the kind of injustice that the administration was perpetuating (Kassam, interviewed, 20 May 2008). Certainly, it was unimaginable to watch someone stripping one's mother and raping her. It was also unimaginable that one had to watch someone taking one's sister by force and/or raping her. Such injustices were common then as some colonial officers took the law into their own hands. Curiously, African home guards working for the colonial government would also do such nasty things in full public view as they regarded themselves to be a law unto themselves.

\section{Betrayal, and amputation of Kassam's leg}

General Kassam recalled that, as the war in the forest raged on, betrayers within their own fighting force increased. The colonial government used a lot of money and other tricks to confuse the freedom fighters. As he noted, it got to a point where some of them, fellow rebels and some members of the rest of society, turned against them. In his view, the colonial government used money to buy information. This easily persuaded the informers to lead the colonial military to the freedom fighters' hiding places, and it was during one such encounter that he was shot at and lost a leg (Kassam, interviewed, 20 May 2008).

After his capture, Kassam was subjected to all forms of torture. In a petition to the British government for war and torture reparations in 2006, he said (Kassam quoted in Kagwe 2014):

I [Patrick wa Njogu alias 'General' Kassam Njogu] was born in the 1920s in [the old] Embu district and joined the Mau Mau rebellion in the Mount Kenya forest in 1952. In 1956, in Kirinyaga, I was shot in the left leg and subsequently arrested and taken to Embu. When I was taken to Embu General Hospital, I remained 
chained to the hospital bed in spite of my grievous bullet wound. I have never felt so much pain in my life. My leg was tightly bound until pus was flowing out freely. Eventually, my left leg had to be amputated above the knee. During the operation to amputate the leg, I was not fully sedated and I could feel each motion as the doctor cut through the bone with a saw. I was in hospital for about a month after the operation, all the while chained to my hospital bed. After the trial, I was taken to Thiba Camp in Mwea. From there, I was transferred to Athi River and then onwards to Manyani. Life was unbearable in Manyani, where we lived like animals. It was more difficult for me as I was now disabled by virtue of having lost a leg. I remember an instance when we were all thrown into the camp cattle dip, which was filled with acaricides. I was not thrown into the dip but a bucket full of the acaricides was poured on me. For a person with one leg, this was the height of cruelty. The guards on many occasions confiscated my crutches as a form of punishment. When I refused to work on account of my disability, I would not be spared the severe beatings that were the norm for refusal to work. (p. 18)

In the course of the researcher's interviews, it became clear that Major Judge (Milton Munene Gachau) was General Kassam's personal doctor while in the forest (Gachau, 20 December 2018). Kassam is said to have been a brave and swift fighter. Nevertheless, he was mainly an administrator and not an army commander like General Chui and General Nene wa Gikungi (alias Kiraigu), or General Kubukubu of Kianjokoma-Embu for that matter. Indeed, when General Chui was commanding the forces in the lightening attacks in the targeted areas, General Kassam was mainly in the camp providing logistics and any necessary strategic work. Certainly, those who had Bren guns or generally good fighting equipment were made to lead as commanders. Generals Nene and Chui were such 'field' cases (Gachau, interviewed, 20 December 2018).

At this juncture, it is worthwhile to consider that there were Kamanda guards or Mau Mau rebels disguised as ordinary citizens who were tasked with the role of protecting Mau Mau rebels who would sneak to the reserves from time to time (Gachau, interviewed, 20 December 2018). The Kamanda guards would advise and caution but they rarely physically fought the enemies of Mau Mau rebels. When the rebels in the forest closed in on the villages, the Kamanda guards would ensure their safety and offer other helpful services that favoured them. They also ensured that cooked food was prepared and sneaked in by some selected women, children and middle-aged girls. In turn, the rebels in the forest consulted them from time to time.

In one instance, the Kamanda guards helped the forest rebels to take a Bren gun from the Inoi Chief's camp, upon which all the people of Inoi-Ndia were punished by having their cows and other properties confiscated by the government as a measure of impoverishing them. The gun was taken by one brave Mau Mau rebel called Sergeant-Major Nubi (whose real name was Ngarari wa Mwaniki) who knew how to use a Bren gun that could fire multiple shots (Gathumbi, interviewed, 03 February 2018). He had fought in the Second
World War during which time he had acquired many military skills. He taught others in the forest how to use a Bren gun. Nubi and Major Judge were captured in 1956, and Nubi died in 2011 (Gachau, interviewed, 20 December 2018).

\section{A one-legged devil?}

General Kassam, in an interview with one of the leading Mau Mau generals in Kirinyaga County who had survived the bombings, beatings and general torture but then died because of poverty (natural?) in 2011, explained that the Mau Mau rebellion was started to defeat the colonial government and reclaim land stolen by the colonial settlers and farmers. Instead, brothers turned against one another as the rebellion reached its peak in 1955. Described as a one-legged devil by the British, Kassam Gicimu Njogu was indeed one of the leaders of the rebellion who worked hand in hand with General Chui (wa Mararo), an equally keen soldier (Gathumbi, interviewed, 03 February 2018).

In his narration, Kassam expressed the regret that many of the people (Kassam, interviewed, 20 May 2008):

' $[I]$ meet always ask me when I joined the Mau Mau. The truth is I did not join the Mau Mau. We formed the Mau Mau. We formed this organisation in 1950.'

He explained that he had earlier joined the Central Union, a grouping of militant youth aligned to the Kikuyu Central Association in 1941 when he first came to live in Nairobi. There was a political union between the Kikuyu and the Luo, and by the late 1940s there was a general consensus amongst many members in Nairobi that an armed uprising was the only way to freedom. The timing was excellent and they had sound reasons for pitching for 1950, as the year of launching an armed struggle for independence in thencolonial Kenya.

Indeed, the Kikuyu, the Nandi, the Luo and the Kamba provided the bulk of the soldiers who went to fight alongside the British in the Second World War. On their return back home, these young men were openly rebelling against the British, as Walton's (1984) theory of reluctant rebels avers (Kassam 20 May 2008). There was something unsettling about the way the establishment in Nairobi treated the African troops who came back home after the Second World War. Many European soldiers were rewarded with land whereas the black troops were simply returned to the barracks or demobilised. That was a perfect reason for mutiny. The bulk of the soldiers who came back from the war were a mutinous lot, and the Kenyans back home were very happy to welcome them into their union.

\section{Kavirondo as part of Mau Mau?}

Kavirondo refers to the western Kenya ethnic groups such as Luo, Luhya, Kisii, Kalenjin and Teso. Kassam's Mau Mau team initially invited their Kavirondo friends from Nyanza to join the Mau Mau fighters in the central Kenya region, telling them that it was the time to start physical attacks on 
the British establishment. Their war was not only against the Europeans, but also against many people who collaborated with them. However, their friends from Nyanza or western Kenya turned down their proposal (Kassam, interviewed, 20 May 2008). At that time, Kassam Njogu had returned home to Kianyaga in Kirinyaga County, but later, in early 1950, he was recalled and informed that the Kikuyu and their cousins Embu and Meru were going all alone as their western Kenya comrades had declined to join them. From there, they stopped calling their outfit Central Union and adapted the name Kimuri (which means flaming torch). Earlier, this organisation was called the 'Forty Group' (Gathogo \& Mugo 2019:3), mainly consisting of men who had been drafted into the army in the early 1940s. A young man called Dedan Kimathi Wachiuri was the most prominent amongst them (Gathogo \& Mugo 2019:3). In an interview, General Kassam (20 May 2008) recalled one evening when they had met at Majengo in Nairobi (where the Gikomba market stands today) to plan the armed rebellion. This was his first encounter with Mathenge Mirugi from Nyeri, later called General Stanley Mathenge, who later disappeared mysteriously without a trace to date. He was tall and light skinned and Kassam instantly liked him. He was a born leader and was reasonably well educated in terms of the standards of that time. They later received support from political groups and personalities like Bildad Kaggia and Paul Ngei. Certainly, they needed arms and ammunition to fight (Kassam, interviewed, 20 May 2008).

According to Kassam's (interviewed, 20 May 2008) recollections, they already had a cache of arms but they still needed more. The quickest way to get this, they argued, was for them to steal what they needed. To do this, they chose to round up all Kikuyu men and women working for European enterprises and in European residences and demanded that they steal firearms for the rebels. For the mission to succeed, they compelled them to swear to secrecy and they stipulated penalties that included execution of betrayers and their family members. Clearly, this was the origin of forced oaths that started to be demanded on a wide scale in central Kenya in 1950. It is the forced oaths they had to take that would result in the rebels' conflict with the Church, especially after some committed Christians had refused to take the oath and ultimately died as martyrs.

\section{Each district to choose its leader}

In an interview (Kassam, interviewed, 20 May 2008), General Kassam recalled that it was at Majengo that six diehard members of the freedom agitators from each region of central Kenya (Meru, Embu (Kirinyaga and Embu counties were in one district then), Nyeri, Murang'a and Kiambu) were asked to volunteer and choose a leader from each group. Kassam volunteered for the group from larger Embu, which included Kirinyaga where he lived. His group chose him to be their leader, meaning he would be the one to administer and supervise oath-taking from Karatina in Nyeri to the Thuci River bordering Meru. He would also lead guerrilla operations in the area. At that time, their aim in subdividing leadership amongst the regions was to make it difficult for the British government to hit the centre (Kassam, interviewed, 20 May 2008). At some point, this subdivision would work against them. To counter this, he organised a military base in the southern part of the Mt Kenya forest where many of them who had not been to war were trained in the basic techniques of handling a rifle by those who had returned from the Second World War. General Kassam had previously received basic military training in present-day Kiambu County.

More rifles and ammunition were sent to Kassam's base from Nairobi, and he soon had 2000 troops from the region that is today Ndia, Gichugu, Mwea, Manyatta, Gachoka and Runyenjesc - in both Kirinyaga and Embu counties. As time went on, they began forcing people to agree to take the binding oath (Kassam, interviewed, 20 May 2008). In Kassam's view, most of the people took the oath out of their own free will, but when a few refused to partake the oath, they had to use force as the fear of betrayal by the nonpartakers was real. They would take a route and make sure everyone was going northward towards his base, where they had to take the oath. Sadly, they executed the few who refused, which was certainly a very unfortunate thing to do, as both the rebels and the colonial government denied civil liberties to 'Others'. Doesn't violence beget violence and an 'eye for an eye' increase more blindness in a nation? Or didn't they learn from the Archimedes principle that the 'buoyant force of an object depends on the pressure exerted by the fluid on its submerged surface?' (Gathogo 2017b:35). Hence, a positive force is met by a negative force of equal measure and vice versa. Undoubtedly, the morale was high for the rebels, as they sought to liberate the country, and the revolution, which at that time had no name, started with remarkable successes having been achieved by the guerrillas, and little did they know that they had triggered events that would be the hallmark of the most painful decade in Kenya's history.

\section{General Kassam as a Moral Leader}

Apart from being a rebel-soldier who was blacklisted by the colonial government as a black devil who deserved death at all costs, General Kassam was a counsellor to the youth and later to the nation (Gachau, interviewed, 20 December 2018). As a moral leader, in his late 70s and 80s, he could publicly bemoan the wastage of public resources, the misuse of the youth by not-so-educated politicians and could still urge the youth to swing into action and reclaim their spaces.

Such 'counselling' sessions were held whenever he addressed public gatherings, youth seminars and workshops. In one of the recorded interviews posted on the web (Kassam, interviewed, 2011), General Kassam, the one-legged General, tells the youth thus:

' $[D]$ on't be told that the future is yours. Take it now, though not by force).' 
'[I]nvest in education and from there, take your stairs. Don't focus on wealth first. Wealth is to be able to manage yourself after acquiring education. Money is evil if not well managed. Why should the most educated remain at the periphery? Wherever you are, ensure people are educated. When people surrounding you are educated, then you are all rich. Wherever and whatever you do, education must be prioritised).'

Kassam's moral leadership was clearly felt even from his forest hideout from where they waged their guerrilla warfare against colonialism. In particular, my interviews with the Mau Mau doctor, Major Judge, whose real name is Milton Munene Gachau (interviewed, 20 December 2018), provided evidence of Kassam's moral leadership. On several occasions, he was heard cautioning his colleagues not to go to their wives in the wee hours of the night, as that was against African culture. Kassam reminded others about African heritage and the belief that traditions were sacred even in times of war, which meant that no marital contact had to be entertained until the end of the war. Total dedication to the agenda of the moment discouraged such contacts in totality. Another instance that revealed his moral leadership was the Battle of Mutitu-kiawaruguru of 1953 when he was in the then Ndia Division. As they planned to move and attack the Mutitu Chiefs' camp, where General Chui led the pack, Kassam cautioned those who had ailments, even minor ones such as flu, not to go to the battlefront. He insisted that war was a matter of life and death and that one had to be healthy and ready in every way (Gachau, interviewed, 20 December 2018). As a combined battalion of almost 100 Mau Mau rebels went to attack the Chief's camp, Kassam stayed at the Gikumbo planning site, which was near the present-day Gathuthuma Primary School, to counsel the rebels who remained behind.

\section{The silence of the Church}

At this juncture, it is critical to ask where the Church was in such scenarios. Was it supporting the humiliation of defenceless citizens? Were the colonial home guards not doubling as the lay leaders of the dominant Anglican Church then, hence creating the wrong impression that the Church and the colonial government were one and the same thing? Indeed, the silence of the Church became more painful than even the actions perpetrated by the colonial administrators. This silence reminds us of the famous quote by the Rev. Dr Martin Luther King (1963) Junior when he noted that, 'our lives begin to end the day we become silent about things that matter'. With such indifference on the part of both the government and the once vocal Church, one expects such scenarios to worsen, unless deliberate action is taken to arrest the situation.

In the nature of things, one can easily get the view that the Church did not respond positively to the heartrending question posed by Evangelist Dietrich Bonhoeffer (1971:16-17) in the 1930s at a critical moment in Germany's history, namely, 'Are we still of any use?'.
Clearly, such a soul-searching question was the climax of the sad portrait of an entire nation that Bonhoeffer painted to illustrate that he differed with the policies of Adolf Hitler in the 1930s. It is still relevant to the situation in colonial Kenya. Perhaps, the Church and the government may need to confess, in the words of (Bonhoeffer 1971), thus:

[W] have been silent witnesses of evil deeds; we have been drenched by many storms; we have learnt the art of equivocation and pretence; experience has made us suspicious of others and kept us from being truthful and open; intolerable conflicts have worn us down and even made us cynical. Are we still of anyuse? (pp. 16-17)

When they were not silent, some Anglican Church leaders in the then Embu district (now Embu and Kirinyaga counties) would stand up in the pulpit to condemn Mau Mau rebels, and would dismiss the movement as the 'work of wayward boys' (Gathogo 2014:21; Gathumbi interviewed, 03 February 2018). In any case, Steve Biko once said that 'the most potent weapon in the hands of the oppressor is the mind of the oppressed' (Steve Biko, cited in Magazi 2008:6). Certainly, it was time for the rebels to nourish their minds by first seeking to stand together. Furthermore, as Martin Luther King once said: 'We will remember not the words of our enemies but the silence of our friends' (Klein 2018:1). Kassam and his team could not ignore the actions and the silence of the Church. They saw the Anglican Church as synonymous with colonialism. Sadly, they forgot the critical role of the Anglican Church in providing education, dispensaries and spiritual food. Considering that most schools belonged to the Church, it is probable that Kassam and other rebels over-played the matter by equating the Anglican Church with the colonial regime.

\section{Conclusion}

The article has described the role of General Kassam, the one-legged Mau Mau General from Kirinyaga County, who commanded the Embu platoon with others such as General Chui, General Kubukubu, Major Judge, Major J. Christo, Major Njee Kambo, Sargent Nubi and Madam Major Matron. The uniqueness of General Kassam (who was once described as a one-legged devil by the British) is that despite having lost his left leg after a shootout in 1953, he was amongst those who survived this deadly war and lived to tell his story. The article has demonstrated that apart from being a brave soldier, he was also a moral leader who adhered zealously to the dictates of African religious heritage, and later embraced some elements of the Christian faith. Even during the 1950s, at the height of Mau Mau war, he would dissuade General Chui (real name, Kibara wa Mararo) from sneaking out of the Mau Mau forest hideouts in the wee hours of the night in order to visit his wife, Gladys Wainoi. Kassam would invoke the indigenous African religious pantheon to insist that during war times, there should be no emotional or sexual contacts amongst spouses, as it is seen as a sacred moment of God and the 
people. Seen in that light, other activities were sideshows that would defile the relationship between God and the community under war with its adversaries. In such cases, the African moral leader would strive to stop it as that would cost them dearly. General Chui, who continued with the habit, was finally gunned down at the Riakiania mushy area near River Rwamuthambi, a few kilometres from his home, Meiria-Kamuiru, in May 1956.

In Kassam's view thus, African religio-cultural heritage dissuades anyone from visiting his or her spouse during the entire period of the war, as doing so amounts to defilement and/or abomination. As noted above, General Chui was in the process of leaving the forest to visit his wife when he was killed and burned ashes in the present day the Anglican Church of Kenya, Kamuiru, Kirinyaga County, in May 1956. A reading of the interviews conducted with Kassam before his death in 2011 reveals that most historians have shied away from addressing the role and place of other members of the Mau Mau movement in the central region of Kenya, especially from the presentday Embu and Kirinyaga, which were once one Embu district from 1933 to February 1963. Did Embu and Kirinyaga counties have active participation in the Mau Mau war of liberation, as in the renowned cases of Meru, Nyandarwa, Murang'a (then called Fort Hall district) and Nyeri? Kassam, as an insider, explained that Kavirondo (western Kenya) and the eastern part of central Kenya were initially united in their quest for freedom from early 1946 to early 1952. After World War II thus, all were united in the agenda of armed struggle, as they all feared that there was no room for dialogue with somebody who treated others in an inhumane way (Ubulwane-Unyama, as opposed to Ubuntu). The movement went on to inspire the formation of uMkhonto we Sizwe (Xhosa for 'Spear of the Nation'), the military wing of the African National Congress (ANC) (Gathogo \& Mugo 2019:22-24). Upon returning home in 1952, Kassam regrettably learnt that Kavirondo and other regions had abandoned this agenda and left it to the central-eastern region of Kenya to continue with the struggle.

By Kassam (2011) telling the youth, as he addressed them, that the future 'is yours, take it but not by force' was he denouncing his youthful rebel activities that earned him a derogatory name 'one legged devil', as noted earlier? Was he regretting his youthful gun battles with the colonial authorities? Or was his new Christian ethics redirecting his past 'eye for eye, tooth for tooth, hand for hand and foot for foot' (Ex 21:24) position of mid-1940s and 1950s to a more dialogical standpoint? Furthermore, his insistence on education for the youth as the miracle for their future shows that he would have preferred dialogue rather than war if colonialism were to return in the 21st century in any form. In a sense, a once militant firebrand of the 1940s and 1950s died as a one-legged moral 'Christian' leader in 2011, although he did not publicly proclaim so, at the octogenarian age of 89 .

\section{Acknowledgements Competing interests}

The author declares that he has no financial or personal relationships that may have inappropriately influenced him in writing this research article.

\section{Author's contributions}

J.M.G. is the sole author of this research article.

\section{Ethical considerations}

This article followed all ethical standards for research without direct contact with human or animal subjects.

\section{Funding information}

The author acknowledges the research institute of Religion and Theology (UNISA) for its research output that enabled me to write this research article.

\section{Data availability}

Data sharing is not applicable to this study as no new data were created or analysed in this study.

\section{Disclaimer}

The views and opinions expressed in this article are those of the author and do not necessarily reflect the official policy or position of any affiliated agency of the author.

\section{References}

Bonhoeffer, D., 1971, Letters and chapters from prison, Macmillan, New York, NY

Gathogo, J., 2014, 'Mau-Mau war and the church in Kirinyaga, Kenya: Accounting for the tension and conflict (1952-1960)', Studia Historiae Ecclesiasticae 40(2), 19-41.

Gathogo, J., 2017a, 'Mau-Mau war rituals \& women rebels in Kirinyaga County of Kenya (1952-1960): Retrieving women participation in Kenya's struggle for independence', Studia Historiae Ecclesiasticae 43(2), 1-16.

Gathogo, J., 2017b, Beyond Mount Kenya Region: 40 Years of theological and practical education at St. Andrew's College, Kabare (1977-2017), Evangel Publishing House, Nairobi.

Gathogo, J. \& Mugo, C., 2019, Chui wa Mararo: The Mau-Mau general who was burnt into ashes, Kairos Book Publishers, Nairobi.

Kagwe, J.N., 2014, 'The Mau Mau reparations case: claimant profiles', Pambazuka News, viewed 27 January 2014, from https://www.pambazuka.org/governance/ mau-mau-reparations-case-claimant-profiles.

Kamau, M., 2017, 'Kirinyaga county honours freedom fighters', Standard Digital, viewed 03 February 2019, from https://www.standardmedia.co.ke/ article/2001241911/kirinyaga-county-honours-freedom-fighters.

Kassam, N., 2011, 'Empowering the youths, by the late freedom fighter General Kassam', YouTube, viewed 29 November 2019, https://www.youtube.com/ watch?v=5v31lasgoAY.

King, M.L., 1963, 'I have a dream', KarmaTube, viewed 07 August 2019, from http:// www.karmatube.org/videos. php?id=54.

Klein, P., 2018, 'The painfulness of silence: Why being silent causes more harm than good', The Thrive Global Community, viewed 25 September 2020, from https:// thriveglobal.com/stories/the-painfulness-of-silence/.

Korir, A., 2018, 'Standard was there to report state of emergency', Standard Digital, viewed 03 February 2019, from https://www.standardmedia.co.ke/ article/2001305445/standard-was-there-to-report-state-of-emergency.

Magazi, D., 2008, 'We are sorry', New Africa, viewed 30 September 2020, from https://newafricanmagazine.com/.

Walton, J., 1984, Reluctant rebels: Comparative studies of revolution and underdevelopment, Columbia University Press, New York, NY. 